\title{
CONFRONTATION AND RECONCILIATION: Muslim Voices of Maluku Conflict (1999-2002)
}

\author{
Muhamad Ali \\ The University of California at Riverside, USA
}

\begin{abstract}
This paper seeks to examine some of the perceptions and attitudes developed by Muslims in relation to the social conflict of Maluku. This paper argues that there were no single views among Muslims with regard to the conflict. Some Muslim hard-liners in general have demonstrated hostile perceptions and confrontational attitudes toward their perceived enemy. They constructed the conflict as a "religious war," and demanded that the Indonesian Council of Religious Scholars (MUI) issue a fatwa that would allow Muslims outside Maluku to fight against the enemy in Maluku. The Muslim moderates, on the other hand, tended to avoid religious vocabularies, while attempting to work out peaceful solutions. The semiofficial MUI, Nahdlatul Ulama, and Muhammadiyyah perceived the conflict as not religiously driven; they viewed the conflict in a more sophisticated way. They saw no need to wage a religious war and no need to issue a fatwa for a national jihas.
\end{abstract}

Keywords: Conflict, Maluku, confrontation, reconciliation, pela gandong.

\section{Introduction}

There is little doubt that the sectarian violence which erupted in Maluku from early 1999 until early 2002 that claimed more than 6,000 lives and displaced some 70,000 others has its historical, political, economic, and religious origins and implications. During the conflict and peace process, speculations, reactions, and perceptions have become parts of the story: some tended to exacerbate the situation, while others wanted to improve it. Muslims, in their diversity, have become part of the players as well as spectators of the conflict. In 
order to get a wider picture, it is important to comprehend how "radical" and "moderate" Muslims perceived the conflict and why they perceived the way they did. This comprehension is important because conflict can be well understood from a dynamic of interconnectedness between three dimensions: 1) context or situation of conflict, 2) perceptions of parties involved directly or indirectly in conflict, and 3) behavior of parties involved during conflict. ${ }^{1}$

Some observers have tended to underestimate the role of religion in Maluku conflict. ${ }^{2}$ There is some agreement that religion serves simply as a complimentary factor in the conflict, emphasizing political, military, and economic factors. For example, Tri Ratnawati concluded that the clashes in Maluku are not a religious war. ${ }^{3}$ Azyumardi Azra equally maintained that religion indeed plays a certain role in this communal conflict, but this role comes only later. ${ }^{4}$ Gerry van Klinken also contended that the conflict lies not so much in inter-religious area. ${ }^{5}$ Likewise, the International Crisis Group (ICG) viewed religion as a minor factor. They stated in a report: "Though often described in terms of a Christian-Muslim fight, at the core of the Maluku violence lies economic and political competition between local interests. Wrapped around this core is a series of external problems ranging

${ }^{1}$ Christoper R. Mitchell, The Structure of International Conflict (London: 1981), as cited by Lambang Trijono, "Peran Komunikasi dalam Konflik dan Untuk Perdamaian," in Lukas S. Ispandriarno et al. (eds), Media-Militer-Politik: Crisis Communication: Perspektif Indonesia dan Internasional (Yogyakarta: Friedrich Ebert Stiftung \& Galang Press, 2002), p. 128.

2 The reason why observers tend to underestimate religious factors in the conflict is perhaps that religion has been regarded simply as an expression of other things; Religion comes down to as a social, cultural, and psychological phenomenon. See Clifford Geertz, Islam Observed: Religious Development in Marocco and Indonesia (New Haven and London: Yale University Press, 1968), p. xii.

3 Tri Ratnawati, "In Search of Harmony in Moluccas: A Political History Approach," Chaidar S. Bamualim et al. (eds), Communal Conflicts in Contemporary Indonesia (Jakarta: Pusat Bahasa dan Budaya IAIN Jakarta \& The Konrad Adenauer Foundation/KAF, 2002), p. 14.

${ }^{4}$ Azyumardi Azra, "Pengantar," in Merajut Damai di Maluku: Telaab Konflik. Antarumat 1999-2000 (Jakarta: Majelis Ulama Indonesia \& Yayasan Pustaka Umat, 2000), pp. xxix; also Azyumardi Azra, "Communal Riots in Indonesia: The Decline of Indonesian Nationalism and the Rise of Separatism," in Bamualim et al. (eds), Communal Conflicts in Contemporary Indonesia, p. 88.

5 Gerry van Klinken, "What Caused the Ambon Violence?," Inside Indonesia, No. 60 (October-December 1999). 
from the national agenda of a resurgent group of Muslim politicians to efforts by some segments of the military to undermine the (former) government of Abdurrahman Wahid."'6

The above suggestions, however, should not overlook the fact that both parties involved either directly or indirectly in the Maluku conflict have perceived each other in religious terms. It can be accordingly argued that there is some truth in the theory of "race between Islam and Christianity" at least in their discourses. This paper attempts to reconstruct the history of the diversity of Muslim perceptions of the conflict that lasted from 1999 to 2002.

In Southeast Asia, Muslims and Christians have been in quarrel since their first contact in sixteenth century. ${ }^{7}$ In light of this, recent conflict in Maluku can be better placed in the context of a long history of Muslim-Christian rivalry in the region. As can be seen below, it was the religious divide that played an important role in the durability and degree of conflict. If religion had not served as a crucial factor, the nature and scope of the conflict in Maluku would have been very different from what was happening.

In general, there are two main perceptions and attitudes of Muslims in relation to the conflict in Maluku: confrontation and reconciliation. Hard-line individuals and organizations have tended to be confrontational, whereas the moderates have been more concerned with peaceful solutions.

\section{Voices of Confrontation}

Some common issues can be found in the radicals' perceptions of the conflict in Maluku: Christianization, separatism, and colonialism which were seen as historically interconnected in Maluku. They also often used strong religious vocabularies during the conflict. In addition, Muslim radicals regarded the traditional institution of pela gandong as an ineffective practice and would not see its future in Maluku because it is un-Islamic and is used by Christians to loosen and even break Islamic ties between Muslims.

6 ICG in Peter Searle, "Ethnic-Religious Conflicts: Rise or Decline? Recent Developments in Southeast Asia," Contemporary Southeast Asia, vol. 24, no. 1 (April 2002), p. 4.

7 See Leonard Y. Andaya, The World of Maluku (Honolulu: University of Hawaii Press, 1993), p. 123; Anthony Reid, "A Religious Revolution," Southeast Asia in the Age of Commerce 1450-1680, vol. II, pp. 132-201. 
Just after the first outbreak on early January 1999, Muslim Ambonese activists were quick to be very convinced that the riot was masterminded by Christian groups. Rivalry between gangs who happened to be different in religion was just triggering factor. They believed that the so-called Reds (Christians) came first and, they claimed, Muslims had to use another color distinguishing them from Christians in the battle (White). From here on, conflicts escalated in different places in Maluku in which Islam and Christianity became identity. Grouping was based on religion, not by brotherhood (pela) or sub-ethnic groups.

The "conspiracy theory" began to be spread by hard-line Muslims. Rustam Kastor, an Ambonese retired Indonesian army officer, who was proud of having military background and claimed to represent 'Muslim side', published a series of book arguing that South Moluccan Republic (Republik Maluku Selatan, RMS) and Christians were the political conspirators who had long planned to destroy and expel Muslims from Ambon, Maluku. His books soon become very popular among local Muslims and Muslims from outside Maluku. What made his books so appealing is that Rustam used a language shared by Muslims. Rustam insisted since the beginning that "this is a religious war." For him, Christians always misused the facts, spread lies, and blamed Muslims for all the riots. Rustam intended to convince Muslims that it was the Muslims who have become the victims of the political conspiracy of Christians. ${ }^{8}$

Rustam insists that the time of attack on the day when Muslims had religious celebration after the fasting month of Ramadhan was not spontaneous. In addition, the fact that the place from which the Christian attackers on the following day came was Central Church at Matanatha (Gereja Pusat Matanatha) indicates, Rustam believed, that Christians were the main actors. Moreover, Rustam observed, the primary targets of insults were all religious symbols related to Islam (Mosque, the Qur'aæ, Prophet Muhłmmad, kubah at the top of the mosque, religious schools (madrasah), religious offices such as the Office of Religious Affairs (KUA) and the Office of Department of Religion (Kandepag). ${ }^{9}$ To justify his belief, Rustam repeatedly quoted a

\footnotetext{
${ }^{8}$ Rustam Kastor, Fakta, Data, dan Analisa Konspirasi RMS dan Kristen Menghancurkan Umat Islam di Ambon-Maluku (Yogyakarta: Wihdah Press, 2000), pp. 60-1.

${ }^{9}$ Ibid., p. 246.
} 
Qur'anic verse: "Never will the Jews or the Christians be satisfied with thee unless thou follow their religions.(II.120)."

Why did Christians attack Muslims? Christians hated Muslims, Rustam speculated, because they felt threatened by the rising Muslim power at the local and national level. ${ }^{10}$ Christians would not be able to establish a separated Christian state if Muslims still live in Maluku. And why did Muslims attack Christian as well? Rustam believed that Muslims felt being discriminated by colonials. Local Christians were better treated, while Muslims were left behind. Injustices were much more severely faced by Muslims than by Christians. Christians could become Dutch soldiers and get good education, whereas Muslims were poor and remained uneducated. Therefore, colonialism has been always negative in the minds of Muslims.

The increasing number of local and migrant Muslims (from other islands, notably Buton, Bugis, Makassar, Java, and Sumatera) was perceived by local Christians as threatening the composition of their society. In Ambon alone, today statistically Protestants account for 51. 92\%, Catholics 5.55\%, and Muslims 42.38\%. Before Muslims accounted for less than $30 \%$. Despite the increasing number, Rustam said, "Ambonese Muslims have no unifying organization, no united leadership, unlike Christians who have Moluccan Protestant Church (Gereja Protestan Maluku, GPM). The strength of Christians in terms of organization has made them easier to initiate a massive attack. For Rustam, the role of Islam in Ambon has been superior than that of Christianity in Ambonese history. Rustam referred to colonial history when, he believed, Muslims were the true patriots, struggling against European powers. Most Ambonese heroes, he believed, were Muslims, including Pattiwane, Kakiali, Gimelaka, Sultan Babullah and Sultan Nuku. ${ }^{11}$

Regarding the tradition of pela gandong, Rustam does not believe in the effectiveness of pela (Moluccan cultural tie) because in practice the RMS and Christians have often broken the tie by prosecuting Muslims in the past and they did it again now. If pela was effective, Rustam claimed, Christians would not have killed their pela brothers. Pela was not supported by Muslims because it was against Islamic teachings.

\footnotetext{
${ }^{10}$ Ibid., p. 122.

11 Ibid., p. 6.
} 
Rustam believed that there was a close connection between Church and RMS. For Rustam, RMS was simply Dutch-created "toy state" (Negara Boneka). He changed the abbreviation RMS which originally meant Republik Maluku Selatan (South Moluccan Republic) into Republik Maluku Sarani (Christian Moluccan Republic). Rustam insisted that with its Chrstian character, RMS was and still is antiIslamic. Hence, Rustam identified RMS with Christianity and Christianity with RMS. Rustam tried to clarify what he meant by his statement that "not all Christians are RMS members, but all RMS members are Christians." ${ }^{12}$, but he was not clear and seemed to remain convinced that RMS and Christianity were inextricably interwoven.

When being attacked, Muslims show their defense as religious obligation (jiha $\gg$ f 3 abi $\triangle$ Alla $>$, war in the path of God). Some Qur'anic verses and Prophetic sayings were cited to justify his interpretation of jiha being "war against Christians". Rustam welcomed the arrival of Laskar Jihad from Java. Rustam regarded this as revenge and help for Muslims in Maluku. Muslims' attacks from May and July 2000 for example were just spontaneous reactions against the previous attacks by the enemy. Rustam regarded Laskar Jihad together with local Muslims as defenders of religion (birbullab) and defenders of the integrity of Indonesian nation (hizbul wathan). Laskar Jihad was seen as Islamic Troops in Afghanistan battling against Soviets. "Allah the Greatest" was yelled in the streets. Laskar Jihad was welcomed by local Muslims; Thalib was regarded by them as ratu adil (millenarian leader). ${ }^{13}$

Soon after the publication of Rustam's books, Harian Suara Maluku, a local Christian newspaper in Maluku, refuted Rustam's opinions and accusations. Suara Maluku responded that Rustam has become another provocateur which fuels further hatred among Muslims towards Christians. Instead of cooling down the situation, Rustam was regarded as making the conflict worst. According to Suara Maluku, Rustam is clearly anti-Christian, not only anti-RMS. For Suara Maluku, Rustam's citations of Christian religion show his anti-Christian propaganda: "As for Christians, they are trinity people, astray, and cross slave. They got lost because they insulted Allah. Their faith is

\footnotetext{
12 Ibid., pp. 4-5.

13 Rustam Kastor, Badai Pembalasan Laskar Mujabidin: Ambon dan Maluku: Mei-Juli 2000 (Yogyakarta: Wihdah Press, 2000), pp. 86-7.
} 
three in one, Maria is His wife and Christ is His son and believed that God has come down from His throne and then resided in a women's womb." Suara Maluku goes on to say that Rustam has insulted Christianity as religion and has provoked Muslims to fight against Christians in Maluku by citing Qur'anic verses allowing war. Rustam was seen by Suara Maluku as having aggravated the victims on Muslim side, while not mentioning Christian victims and casualties at all. Suara Maluk $u$ demanded Rustam be brought to police and court for all these insults. ${ }^{14}$

Rustam's articles were published during the conflicts, which were then refuted by Suara Maluku and other newspapers. Rustam answered back the refutations from Suara Maluku, still being convinced by his own speculations. Rustam was very proud of having a military background and claims to represent a Muslim voice in Maluku. Rustam's books attracted wide audience, especially amongst hard-liners in Maluku but perhaps more significantly outside Maluku.

Rustam Kastor was appointed to be a committee member on Ambon case by Indonesian Council of Religious Scholars (Majelis Ulama Indonesia, MUI) of Maluku but was then replaced by Thamrin Ely, another Ambonese because, according to Thamrin, Rustam had a "personal motive". The former President Abdurrahman Wahid considered Rustam to be one of the provocateurs in Maluku, but Wahid did not bring him into trial. ${ }^{15}$

Thamrin Ely, an Ambonese Muslim activist, the secretary of MUI of Maluku branch, and the president of National Mandate Party (Partai Amanat Nasional, PAN) of Maluku branch, believed in similar scenario that Christians planned the attack on January 19, 1999. One of the indicatios was that the "Reds" emerged before the "Whites". Thamrin Ely denied the accusation from Christians that Muslims had prepared the war before that day by building action units (satuan tugas). Like Rustam Kastor, Thamrin Ely was convinced that elements of the RMS and Christians were behind the attack. ${ }^{16}$

\footnotetext{
14 Rustam Kastor, Suara Maluku Membantah, Rustam Kastor Menjawab (Yogyakarta: Wihdah Press, 2000), pp. 23-65.

15 Ahmad Suaedy et al. (eds), Luka Maluku Milter Terlibat (Jakarta: Institut Studi Arus Informasi, 2000), pp. 23-9.

${ }^{16}$ Ibid.
} 
Thamrin admitted that both polarization of religion and "national political scenario" were the main factors behind the conflict. Yet, Thamrin disagreed with the marginalization theory which holds that Christians became increasingly marginalized in local economy and politics. In fact, Thamrin argued, there were still more Christians in the government officials. Therefore, it is not true to point economic gap as an important factor. There is something more religious. Thamrin believed that religious polarization is a colonial legacy. "Christian Ambonese peoples were treated very well by European colonials: good education, Malay language learning, and most became colonial bureaucrats albeit at lower level. Only Christians were allowed to become Royal Netherlands East Indies Army (KNIL) soldiers, whereas most Muslim immigrants came to Ambon for trade and entrepreneurship. As new Muslim pilgrims became increased, Middle Eastern traders came to Ambon as well. Colonialism and Christianity were so close that as nationalism came, Ambonese Muslims regarded it as a hope, whereas Christians viewed it as a threat. ${ }^{17}$

Another Ambonese Muslim activist who believed in Christianization project behind the riots is Umar Tuasikal, who lived in Java and was active at Association for Moluccan Muslim Families (Himpunan Keluarga Muslim Maluku, HIKMMA). In his book published on January 2000, Umar insisted that the root cause of the conflict has been religious antagonism, a continuation of Perang Salib (the medieval Crusades). Umar considered the Christian attacks in early 1999 as part of a grand 'mission sacrée. He quoted the term "La Conquete du Monde Musulman" to refer this phenomenon. Umar believed, Christian imperialists came to Maluku for spices and for converting Maluku people into Christianity. In this book, Christians were perceived as 'aggressors' and therefore Muslims had the obligation to defend their home, life, and religion (jibal Umar cited Qur'anic verses to justify this belief in jibale "Fighting is prescribed upon you and ye dislike it. But it is possible that ye dislike a thing which is good for you, and that ye love a thing which is bad for you. But Allah knoweth and ye know not." (II: 216) For Umar, RMS is in fact Republik Maluku Serani (Nasrani, Christians).

17 Mansur Alkatiri, "Politik dan Kecemburuan Berbungkus Agama," Ummat, No. 35, (March 15, 1999), pp. 23-4. 
Umar believed that the bloody Idul Fitri conflict has been long planned by Christian RMS. Umar was convinced that through radios, Christian groups had already consolidated their people from Moluccan Protestant Church (Gereja Protestan Maluku, GPM). Umar writes, "In a meeting in a church in Lateri village in the eastern part of Ambon Christians decided the time for massive attack against Muslims. There was no agreement between old and young people at the meeting. The young wanted the attack to be held at the first takbirat the time of Idul Fitri prayer, whereas the old wanted it soon after the prayer when Muslims were neglectful." Umar accused that the plan was not only known by Christians in Ambon, but also in the Netherlands and other regions in Indonesia. ${ }^{18}$ Umar believed that Christians had attempted to shift the real cause from religious antagonism to economic, political, and social gap. Muslims, he believed, have been victimized by a wider Christian conspiracy. Umar justified his belief by referring to Samuel Huntington's theory of clash of civilizations. For him, Eastern Indonesia is being planned to become "Eastern Christendom".

After ten months of conflict, M. Husni Putuhena, another Ambonese activist, published a book entitled 'Buku Putih Tragedi Kemanusiaan dalam Kerusuban di Maluku” (A True Story: Human Tragedy in Maluku Riots). Putuhena concluded that Idul Fitri violence was engineered by both Church in Maluku and RMS in the Netherlands and was supported by Christian organizations in Maluku. The timing of the attack (Idul Fitri, Muslim celebration after Ramadhan fasting) was chosen purposefully, indicating that their intention was religious. Regarding the role of RMS, the date (January 19) was one day after the anniversary of RMS (January 18 th 1950). Putuhena believed that the attack was aimed to reduce the number of Muslims in Maluku, either through slaughtering or forced exodus to allow Christians to separate from Indonesia. The burnings of mosques and Muslim houses were believed to be a revenge of Maluku Christians for the previous burnings of Church outside Maluku, especially during Ketapang riot on November 22, 1998. The attack was also believed to have a global aim of Protestant Oikumene (one place, one Church, one God). Putuhena believed that Christian leaders used two means: violence and peace, but they provoked peoples with lies and facts manipulation. The attack

18 Umar Tuasikal, Quo Vadis Modus Vivendi Antar Umat Beragama di Ambon (Jakarta: Himpunan Keluarga Muslimin Maluku, 2000), p. 57. 
also shows, Putuhena argued, jealousy, revenge, and hatred on the Christian side toward Muslims. ${ }^{19}$

While the above activists are local, hard-line groups such as Laskar Jihad came when the conflict had occurred for more than one year (April 2000). The arrival of Laskar Jihad does not suggest that local Muslims were not perceiving the battle as religious. Before their arrival, religious polarization had existed. The arrival simply exacerbated the existing polarization and made much more violence. Laskar Jihad (literary meaning "holy war troops"), was a paramilitary division under the Communication Forum for the Followers and the Community of the Prophet (Forum Komunikasi Ablu Sunnah wal-Jama'ab, FKAWJ). The chief, Ja'far Umar Thalib was a charismatic Wahhabis cleric, who went to Afghanistan from 1987 to 1989, driven by his sense of Islamic solidarity. Originally, the founding of FKAWJ can be seen as a search for authenticity, but it turned out to be anti-Christianism, antisemitism, and anti-Americanism. But Laskar Jihad represents a later phase of revivalism, namely "neo-fundamentalism". FKAWJ had different social activities but Laskar Jihad was specifically aimed to be a militia paramilitary group. ${ }^{20}$

Thalib appeared to be both religiously and politically radical. $\mathrm{He}$ often criticized the government especially regarding what he believed as insulting Islamic interests. Although Ja'far once denied himself as being radical, saying: "I am not radical. I tend to be rational in seeing all problems; political principles that I take can be discussed rationally and responsibly," Ja'far cannot deny the facts that his activities were largely radical religiously and politically. Ja'far declared "Jihad resolution" (fatwa $\rightarrow$ r religious edict on jiba in April 2000. FKAWJ based this fatwa $\gg$ n the fatwas $>$ of Jihad in Maluku issued by Middle Eastern Salafy muftis, including 'Abd al-Muhşin al-'Abba from Medina, Muqbil b. Ha $>$ l-Wa fili $>$ from Yemen, Ra

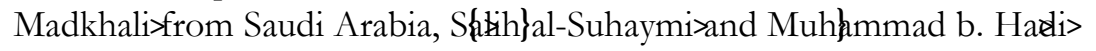
al-Madkhali from Medina. On the basis of these fatwas? declared the "Moluccan War", defending Islam from Christian attacks. Quoting a medieval scholar Ibn Taymipar, Thalib said, "Should our enemy attack

19 M. Husni Putuhena, Buku Putih Tragedi Kemanusiaan dalam Kerusuban di Maluku. (Maluku: Lembaga Eksistensi Muslim Maluku, 1999), pp. 52-55.

20 See Noorhaidi Hasan, "Faith and Politics: The Rise of the Laskar Jihad in the Era of Transition in Indonesa," Indonesia, 73 (April 2002), pp. 145-69. 
Muslims, to confront the attack would be an obligation incumbent on the Muslims who are being attacked and it would be also compulsory for other Muslims to help them."21

Ja'far knew that his decision was controversial but he did not care about other opinions and the government's interdiction because, he believed, quick action was necessary or Muslims in Maluku would be destroyed by the Christian RMS. Ja'far observed that there was manipulation of 'conflict mapping' about what was happening around Maluku conflict, but he was not clear what he meant by this. Yet, Ja'far claimed, "what is happening in Maluku is not a conflict between Islam and Christianity, but between RMS or neo-RMS rebels and Indonesian nationalists. Therefore, all loyal Muslim nationalists should fight against the rebels." 22 Here it becomes obvious that the reason why he used the vocabulary of jiha was to attract wider audience of Muslims: not only Ambonese, but also and mostly, Javanese and other Muslim Indonesians. Ja'far succeeded in trying to appeal to a wider community by emphasizing that the issue at stake in Maluku was about Christian separatism versus Muslims nationalists, while using strong religious vocabularies (fatwa جnd jibal).

When the situation in Maluku after about two years became increasingly under control since the government carried out reconciliation programs, Thalib disbanded Laskar Jihad and FKAWJ after a meeting of the Executive Board in October 2002. The disbanding was taken because the original mission had become deviated with "too political" activities. The original missions were, Thalib himself explained, to carry out religious duty to help Muslim brothers in conflict area when the government was incapable. When the government controlled the situation, Laskar Jihad saw no need to continue its activities. ${ }^{23}$

It seemed that Laskar Jihad' $\mathrm{s}$ withdrawal from Ambon and Maluku received positive response from different elements, but some local Muslims admitted that they still needed Laskar Jihad. Some argued that it was time for the national government to deal with RMS which was widely believed among Muslims as the main cause of the conflict in Maluku. It was said that fatwas from Arab Saudi influenced

\footnotetext{
${ }^{21}$ Ibid., p. 166.

22 Tempo, March 2002.

23 Tempo, February 10, 2003.
} 
the decision to withdraw. This indicates, as a Muslim historian Azyumardi Azra argues, that there was a direct network between Indonesia and the Middle East. Others, like Amidhan, the chief of MUI, contended that the withdrawal signified that people had begun to trust their government in solving the conflict. ${ }^{24}$ However, some Muslim elements praised the various efforts of Laskar Jihad in Maluku. An Islamic newspaper, Republika, appreciated the presence of Laskar Jihad in Maluku for they had benefited Muslims in Maluku. Laskar Jihad proved to have assisted and protected local Muslims from being defeated by the enemy; they were also praised of having all the courage to defend Indonesia from RMS separatism wishing for national disintegration. Even the governor of Maluku, Saleh Latuconsina, was reported to have been surprised by the withdrawal of Laskar Jihad. Saleh admitted that now with the absence of Laskar Jihad, social service (religious preaching, free medical aid, and education) that was initiated and carried out by Laskar Jihad during their arrival in Maluku now stopped operating. Saleh observed that many local Muslims in Maluku complained the withdrawal because they still needed Laskar Jihad.

Another hard-liner involved in the conflict is Front to the Defenders of Islam (Front Pembela Islam, FPI) of Maluku. The front issued a statement called "Intensive Analysis: Data and Facts on Maluku Conflict", in which there are some indications about the role of RMS and Christianity in Maluku conflict. FPI claimed that the attack was planned by Church, referring to a thesis by DS A.N. Radjawane, entitled "Islam in Ambon and Haruku", which indicates that Christianization project has long been planned: "Nowadays a concrete plan in the evangelist strategy on Muslims has not been possessed by Gereja Protestan Maluku (GPM), but we should be grateful that Church has began to open their eyes towards the efforts of Christianization in Maluku." 25

Another hard-line organization which has the main base in Jakarta is Indonesian Committee for Islamic World Solidarity (Komite Indonesia untuk Solidaritas Dunia Islam, KISDI). KISDI has been famous for their vocal voice for "Islamic causes". HA Sumargono, the secretary general, believed that Maluku conflict has turned out to be a religious war, not

\footnotetext{
24 Republika, October 17, 2002.

25 Ibid., p. 67.
} 
simply ordinary bloody riots. KISDI demanded the government and security apparatus to be sincere and fair in solving the Ambon case and not to hide the real problem, which is Christianization-separatism. KISDI believed that Ambon has become the field of jibal? This decision was taken without prior fatwa $\rightarrow$ ssued by Islamic organizations such as MUI. "The situation in Ambon", Sumargono observed, "is very worrying and this could harm the future of Maluku as part of the unitary state of Indonesia." He said that Muslim victims in Ambon are shabit just like those who die in fight in the name of God. Muslims' condition was believed to become worst as they were continuously attacked and expelled from their home and village. The attacks against Muslims must be ended, Sumargono demanded. In the meantime, Sumargono asked, "Don't take weapons from Muslims right away because they still need them for their defense against others' attacks. Christian leaders must be more active in ending the violent acts conducted by their followers." 26

The role of those hard-liners seem to suggest that a deadly ethnic riot like in Maluku has proved to serve as the proving ground of extremist organizations, which sometimes provides leadership. The riot may test mettle, cement esprit de corps, and aid their recruitment efforts. Laskar Jihad and FPI were born out of the violence and contributed to a considerable share to later violent episodes. Violence may thus give enduring organizational expression to the polarization of sentiment. ${ }^{27}$

Activists from outside Maluku have been also involved in justifying the conflict in Maluku. An Islamic politician who was also a member of Indonesian parliament (DPR), Abdul Qadir Djaelani equally believed in religious conspiracy theory. Djaelani placed Maluku conflict in the context of global and national anti-Islamism. It was designed by a global Christian force which had long intended to separate Maluku from Indonesia. Djaelani pointed to several examples which show how Christian leaders and commoners were anti-Islamic. He mentioned peoples like a Jesuit General Leonardo Benny Murdani, a Protestant Major General Theo Safei, and F. Litaay. Djaelani regarded Maluku conflict in early 1999 as a continuation of previous Christian attacks on

\footnotetext{
${ }^{26}$ Kompas, July 30, 1999.

27 Donald L. Horowitz, The Deadly Ethnic Riot (Berkeley, Los Angeles, London: University of California Press, 2001), p. 12.
} 
Muslims. Gereja Protestan Maluku and RMS had a together plan to attack Muslims. President of RMS in the Netherlands, F.J.L. Tutuhatunewa, was reported to have sent "war fund" to Ambon. ${ }^{28}$ An indication of the involvement of RMS is the Declaration of Front for Moluccan Sovereignty (Front Kedaulatan Maluku, FKM) on December $18^{\text {th }} 2000$ in Ambon which stated that the Indonesian government is an imperialist; TNI (Indonesian army) and Polri (Indonesia Police) are "occupying soldiers". ${ }^{29}$ In addition, Djaelani believed, pela gandong is contradictory to Islam because it creates secular relationships and unknown in Islamic teachings.

Another activist, Al-Chaidar, who is Acehnese, organized The Great Preaching/Meeting (Tablig Akbar) attended by some 100, 000 people at National Monument Jakarta on January $7^{\text {th }}, 2000$. The Great Meeting declared jibato Ambon. In one of his articles, Al-Chaidar believed that Maluku is and should always be Islamic. He asked people: "Where does the name Maluku come from? He responded: "It comes from an Arabic term "Maliku or Muluk" which means "the land of lords" and is applied originally to a chain of five islands, to spice islands". It was only when Portuguese and Dutch colonized Maluku respectively that Maluku peoples became Christianized. Hence, Christianization and Colonialism for Al-Chaidar were identical. AlChaidar called Maluku conflict as "the Butchering of Muslims as an expression of fear on the side of Ambonese Christians." Al-Chaidar relied on Robert Chauvel's thesis on the threat of RMS against Indonesian nation-state and Muslim-Christian race since colonial times. Al-Chaidar for example cited Chauvel's statement that "the Republik Maluku Selatan (Republic of South Moluccas, RMS) and its suppression was (sic) a tragedy for Ambonese society. It was the worst possible way in which Ambon could have part of independent of Indonesia." 30 It follows from this that, Al-Chaidar believes, the Christian RMS played a role in the recent conflict in Maluku.

As has been often suggested, mass media played an important role in seeking and spreading reports and opinions. A number of hard-line

\footnotetext{
${ }_{28}$ Tempo, December 20-26, 1999.

${ }^{29}$ Abdul Qadir Djaelani, Agama dan Separatisme menjadi Landasan Konflik. Maluku dan Poso (Jakarta: Yayasan Pengkajian Islam Madinah Al-Munawwarah, 2001), p. 8.

30 Richard Chauvel, Nationalists, Soldiers, and Separatists: The Ambonese Islands From Colonialism to Revolt 1880-1950 (Leiden: KITLV Press, 1990), p. 393.
} 
Islamic magazines included Media Dakwah (Islamic preaching magazine) and Sabili (meaning My Path), with the latter claiming more than seventy thousands exemplars. In general, these media believed only their own version of events. Media Dakwah (MD), an Islamic magazine with wide circulation among Muslim activists, also depicted the conflict in Maluku as religious and Maluku as the field of Jihad for Muslims. MD equated Maluku war with the medieval Crusades. They cited how Christians used religious symbols when attacking Muslims: Long Live Jesus, Islam Coward, Bravo Israel! MD was mostly concerned with the victims from Muslim side. MD accused Association for Indonesian Churches (Persekutuan Gereja-gereja Indonesia, PGI) for manipulating the fact that Muslims became the main victims. Although PGI officially refuted the description of Maluku violence as 'ethnic cleansing', 'religious cleansing' and the like, MD still believed in these. MD praised itself and other media (such as Sabili, Aspirasi, Abadi, and Saksi) that attempted to report Muslim side when other media (mostly Christians) did not give enough attention to Muslim victims. MD complimented their reports with an interview with Abdullah Hemamahua, ex-President of Association of Islamic Students (Himpunan Mahasiswa Islam, HMI) and Masyumi party leader, who viewed Maluku war as being religiously-driven. ${ }^{31}$

Media reports on how more and more Muslims have been defeated or became victims continuously worried Muslim activists. Sabili ceaselessly reported that Maluku conflict brought about tragic stories felt by Muslims as insulting their religion. One of the stories came from an ima (an Islam leader) of Mosque Al-Huda in Ahuru, named H. Husen Toisuta, telling how on February 27th 1999 , Christians shot Muslims in the midst of their praying at the mosque. Another witness from Council for Indonesian Islamic Propagation (Dewan Dakwah Islamiyah Indonesia, DDII) reported that he saw how Ambonese Christians and local apparatus slaughtered Muslim peoples. These stories and the like reported by Islamic journals and verbal communicants have led 'radical Muslims' to hold demonstrations and to wage war against those whom they viewed as enemy. Religious sentiment was so deep that going to Ambon was regarded as the only alternative they had.

31 Media Dakwah, Ramadhan 1429/December 1999. 
In this deeply psychological situation, it should not be surprising that street demonstrations took place in Java, Sumatera, Sulawesi, and other major cities as Muslims felt being increasingly victimized in Ambon, while the government was regarded impotent. Demonstrations were held by many hard-line organizations, including Association for Action of Indonesian Muslim Students (Kesatuan Aksi Mahasiswa Muslim Indonesia, KAMMI), Association for Intra-campus Muslim Students (Himpunan Mahasiswa Muslim Antar Kampus, HAMMAS), Indonesian Committee for World Islamic Solidarity (KISDI). Now they began to conceive of the conflict as religious war. They demanded that National MUI should issue a fatwa to allow Muslims to go to Ambon as holy warriors (muja dira. An Islamic journal called Tabloid Aliansi Keadilan saw enough reasons driving the issuance of fatwa $>$ instructing jiha Maluku. First, the violence in Maluku was not an ordinary criminality; it was a planned religious violence against Muslims. Some churches such as Church at Hilo played a role in mobilizing Christians before attacking Muslims. Second, there was no real effective solution given by local and national government; the Indonesian army and police were not quick to prevent and reduce the increasing violence. In these uncertainties and dissatisfaction with Jakarta's government on resolving the violence, with the perceived devastating situation in Maluku, Thalib with his Laskar Jihad took the opportunity by sending thousands of Islamic troops to Ambon, ignoring the prohibition by the government. Besides Laskar Jihad, a number of holy war posts began to recruit Muslim volunteers as warriors to be sent to Ambon. There were a number of established posts including those of Pemuda Bulan Bintang, a youth institution under Partai Bulan Bintang (Party of Moon-Star), Islamic Propagation Union (Majelis Ta'lim Radio Dakta Bekasi) Association for Action of Indonesian Muslim Students (KAMMI), Movement of Islamic Youth (Gerakan Pemuda Islam, GPI), and Front for Islamic Defenders (Front Pembela Islam, FPI). ${ }^{32}$

How did Christian groups and media respond to the above speculations and accusations? It seems that Christian media tried to provide their own version. Although it is not my intention here to examine Christian views on the conflict, it is worth noting to mention

32 "Bom Hidup Mujahidin Menunggu Komando," Abadi, no. 18 (March 17th, 1999), p. 18. 
one independent Christian-based organization to have some insight about the Christian side. Jubilee Campaign, an interdenominational Christian human rights organization which worked for persecuted Christians all over the world, in their report in December 1999 criticized radical Islamic media, leaders, and organizations who depicted the conflict in Maluku as a field of jiha for Muslims against Christians. As for the background and the salient points of the conflict, Jubilee believed that the sectarian conflict was master-minded by Islamist Indonesian army (TNI) officers and Islamist organizations in Indonesia in an effort to change the constitution of Indonesia from a pluralist basis to the one that is flavored by Islamic Law and to Islamize the country as a whole.

Jubilee Campaign also refuted the allegations put forward by Islamic radicals that RMS masterminded the conflict. Jubilee asserted, the Christians have strongly reputed this allegation and RMS leaders in Holland (both Christians and Muslims in the movement) have also strongly denied their involvement in Maluku conflict. Jubilee Campaign requested to the Foreign Office and the European Union to pressure the Indonesian Government to prosecute all parties who incited and carried out unjustified violence, including those who are calling for jiha and ensure accurate reporting by the media and that that they do not incite religious hatred. ${ }^{33}$ Hence, regarding Muslim and Christian version of events, suffice it to quote Gerry van Klinken: "From here on, events escalated as each side believed only its own version of events. Muslims spoke of halting the 'Christianization' drive. Christians spoke of Islamic 'fanaticism' in Jakarta, while some spoke nostalgically of the Christian-dominated South Maluku Republic breakaway movement of 1950." 34

\section{Voices of Reconciliation}

Unlike the above mentioned individuals and organizations, MUI attempted to stand in all sides in response to the on-going conflict in Maluku. K.H. Ali Yafie, the president of MUI, contended that Maluku conflict has been multi-dimensional: historical, cultural, social, political, and religious. Historically, European colonialism had a bad impact on

\footnotetext{
33 Jubilee Campaign United Kingdom, "Analysis of the Sectarian Conflict in Maluku and Its Role in the Islamisation of Indonesia,", A report issued in December 1999.

34 Gerry van Klinken, "What Cause the Ambon violence?," Inside Indonesia, No. 60 (October-December 1999).
} 
social relationship in Maluku: Muslim-Christian divide which could manifest itself in inter-religious violence. Consequently, Maluku societies have been filled with prejudices and distrust. Pela Gandong was not as effective as people have expected. In response to what was happening in Maluku since January 1999, the National MUI had attempted reconciliational approach. MUI invited all parties involved in conflict not to repeat Muslim-Christian conflict in medieval history (Crusades) as well as in Bosnia and Kosovo. Religious rivalry must be ended. MUI claimed that they had attempted since the outbreak of violence to find peaceful solutions. They hold meetings with religious leaders from Islam and Christianity. MUI asked Muslims to take peaceful measures and to avoid provocations. MUI established a team for fact finding (Tim Pencari Fakta) and coordinated humanitarian aids. MUI rejected the declaration of war by some radical elements, refused to issue a fatwa \o go to war in Maluku demanded by them. There would be no "National Jihad" in the sense that all Muslims in Indonesia fight against Christians in Maluku. The obligation of Jihad can only be applied to those peoples in Maluku in defense of their own place. Muslims outside Maluku can only aid Maluku in humanitarian terms. ${ }^{35}$

The two biggest religious organizations, Nabdlatul Ulama (NU) with some 35 millions membership and Muhammadiyyah with 30 millions followers, went in the same line. They did not perceive the conflict as the hard-liners did. Thus, for example, as $\mathrm{KH}$ Hasyim Muzadi, the president of NU, said, in Surabaya on April $8^{\text {th }} 2000$, NU does not support solidarity actions in the form of Jihad in Ambon. Jihad with violence and agitation would aggravate, rather than solve, Maluku conflict. Any kinds of agitation are not helpful in solving the conflict. NU will only support the role of inter-religious leaders who would come to Ambon to calm Ambonese peoples by dialogue and persuasive approach. ${ }^{36} \mathrm{NU}$ leaders seem to believe that the series of conflict in Maluku were caused by complex factors that there was no need to bring it into a religious war. To believe that the conflict is a religious war would lead to a more hostile attitudes in both sides and the consequences would become worst and longer. Likewise, the

\footnotetext{
35 MUI, Merajut Damai di Maluku: Telaah Konflik. Antar Umat 1999-2000 (Jakarta: MUI \& Yayasan Pustaka Umat, 2000), pp. vii-ix.

${ }^{36}$ Kompas, April 10, 2000.
} 
Muhammadiyyah leader, Muhammad Syafii Maarif, also in many occasions stressed the non-religious character of the conflict.

The moderates' views were not surprisingly supported by the government, especially in this case, the Ministry of Religious Affairs. Despite their shortcomings in solving the conflict in the first and second year, the government attempted to stand in all sides. The then Minister of Religious Affairs, Malik Fadjar, asserted that Ambon conflict is not a religious war. He maintained that if Ambon conflict is brought into religious conflict, the solution would become more difficult and conflict area would be more spreading. ${ }^{37}$

It is now also important to see some public opinion about the conflict. Public opinions seem to sustain the perceptions of the moderates and government officials. At least, as the following polling suggested, the majority of people in Jakarta viewed the conflict in Maluku as non-religious. Some 500 respondents living in Jakarta were asked a number of questions in late January, 1999 by Tempo, a Jakartabased weekly periodical. ${ }^{38}$

How is inter-religious relation so far in Indonesia?

\begin{tabular}{clccc}
\hline No & & Total & Muslim & Non-Muslim \\
\hline 1 & Very tense & $2 \%$ & $1 \%$ & $4 \%$ \\
2 & Tense & $23 \%$ & $23 \%$ & $17 \%$ \\
3 & Normal & $41 \%$ & $43 \%$ & $39 \%$ \\
4 & Tolerant & $33 \%$ & $32 \%$ & $38 \%$ \\
5 & Very good & $1 \%$ & $1 \%$ & $2 \%$ \\
\hline & Total $\%$ & $100 \%$ & $100 \%$ & $100 \%$ \\
\hline
\end{tabular}

\begin{tabular}{ll}
\hline Is religion a source of conflict? & \\
\hline Yes & $23 \%$ \\
No & $61 \%$ \\
Doubtful & $16 \%$ \\
\hline Is Maluku conflict religious? & \\
\hline Yes & $16 \%$ \\
No & $68 \%$ \\
Doubtful & $16 \%$ \\
\hline
\end{tabular}

What factors in religion can cause conflict?

\begin{tabular}{ll}
\hline Religious People misinterpret religion & $59 \%$ \\
Religious Solidarity & $29 \%$ \\
\hline
\end{tabular}

\footnotetext{
37 Kompas, March 4, 1999.

38 "Perang Agama, Siapa Bilang?," Tempo, 2-8 February 1999, pp. 192-3.
} 


\begin{tabular}{ll}
\hline Religious Teachings & $1 \%$ \\
No answer & $11 \%$ \\
\hline What are real causes of conflict? & \\
\hline Groups Desiring Chaos & $85 \%$ \\
Political Elite Conflict & $47 \%$ \\
Socio-economic Jealousy/Gap & $35 \%$ \\
Ethnic Difference & $9 \%$ \\
Other factors & $3 \%$ \\
\hline
\end{tabular}

As can be seen from the above figure, some 60 percent believed that the conflict in Maluku was not caused by religion. Some 68 percent believed that the conflict was not a religious war. A significant number of respondents still considered the conflict as religious. If religion becomes a factor, religious misinterpretation will be responsible for any conflict. The character of religion as a source of identity will also bring about conflict, while religious teachings serve a minor role in creating conflict. The polling suggests that people still believe in the innocence of religion, while they blame political interest as the main source of conflict (85 percent respondents). Some percentage (35 percent) considers socio-economic jealousy as a factor, while ethnic difference has a minor place in creating conflict. Since this polling was done on the same month of the first riot (January 1999). The polling indicates that religion was not the most important factor.

\section{Conclusion}

This paper has attempted to examine some of the perceptions and attitudes as expressed by radical and moderate individuals, organizations, media as well as the public toward the conflict in Maluku. This has argued that there were no single views among Muslims concerning the conflict. The radicals in general have demonstrated hostile perceptions and confrontational attitudes toward the enemy. They perceived the conflict as a 'religious war', and demanded MUI to issue a fatwa that would allow Muslims outside Maluku to fight against the enemy in Maluku. Some organizations, notably Laskar Jihad, decided to go to Maluku for jiba on fatwas from Saudi 'Ulama? In their reasoning, the radicals identified the conflict with the Medieval Crusades (perang salib), and accused Christian as separatists (Republik. Maluku Selatan, RMS) as the master-mind of the first massive attack on January 19, 1999. 
The Muslim moderates, on the other hand, avoided religious vocabularies, while attempting to work out peaceful solutions. The semi-official MUI, Nahdlatul Ulama, and Muhammadiyyah perceived the conflict as not religiously driven; they viewed the conflict in a more sophisticated way; they saw no need to wage a religious war and no need to issue a fatwa for a national jiha

Although both radical and moderate strands of Islam made a link between the contemporary conflict and the colonial past, they saw it in a different way. The radicals tend to identity Christianity with European colonialism in such a way that justifies them to show hostility toward Christians, whereas the moderates were carefully reluctant to identify Christianity with European colonialism, considering the fact that colonial history and Christian history in Indonesia could have been different. Colonial history for the moderates should not be used as a justification for Christian-Muslim conflict.

In their polemics, the radicals tend to associate Christianity with colonialism and separatism. Muslim-Christian conflict in Maluku can be seen as part of the history of mutual distrust in Indonesia. ${ }^{39}$ Radical Muslims perceived increasing Christianization in large part of Indonesia as also threatening the integrity of Islamic society (ummah). On the other hand, Christians are largely worried about what they perceived as Islamization and the establishment of Islamic State. Christians often viewed Islamic revival as similar to radicalism or fundamentalism. The idea of constitutionalization of the Islamic law has been regarded as threatening the pluralistic character of Indonesian nation-state.

Another point of difference has been the perception of the traditional institution of pela gandong. In their writings, some radicals underestimated the role of pela gandong in creating tolerance in Maluku especially for Muslims, and regarding this tradition as un-Islamic. While seeing that the conflict showed the fragility of pela gandong, the moderates still hoped that pela gandong can be revitalized and redefined.

Why did the radicals perceive the conflict the way they did? It can be argued that radicalism in Indonesia can be seen as an indication of a

39 See for example John L. Esposito, Islamic Threat: Myth or Reality?, revised edition (New York and Oxford: Oxford University Press, 1995), pp. 55-62; Alwi Shihab, "Pertemuan Islam-Kristen di Indonesia: Sebuah Tinjauan Historis," in Islam Inklusif: Menuju Sikap Terbuka dalam Beragama (Bandung: Penerbit Mizan, 1998), pp. 3- 36. 
"crisis of reason" and "the victory of passion". Irrationality was pervasive during the conflict: rumors and misuse of religious language. The latter is because religion itself provides ambivalent functions. For the hard-liners, religious imagery is easy to be used for their communalistic purposes, especially when they see no alternative to their own faith. There can be found religious bigotry, prejudices, suspicion, and fanaticism. There is lack of moderate religious understanding as well, partly because of poor and exclusive religious education which emphasizes truth-claim absolutism, rather than tolerance. []

\section{Bibliography}

\section{Books and Articles}

Alkatiri, Mansur. "Politik dan Kecemburuan Berbungkus Agama." Ummat. No.35/15 March 1999.

Al-Shahrastany. Al-Mila wa al-Niha VVol. 2. Cairo: Maktabah al-Husain al-Tijariyyah. 1948.

Andaya, Leonard Y. The World of Maluku. Hawaii: University of Hawaii Press, 1993.

Azra, Azyumardi. "Pengantar," in Merajut Damai di Maluku: Telaah Konflik Antar Umat 1999-2000. Jakarta: Majelis Ulama Indonesia \& Yayasan Pustaka Umat. 2000. pp. x-xix.

-. "Communal Riots in Indonesia: The Decline of Indonesian Nationalism and the Rise of Separatism," in Chaidar S. Bamualim et al. (eds). Communal Conflicts in Contemporary Indonesia. Jakarta: Pusat Bahasa dan Budaya IAIN Jakarta \& The Konrad Adenauer Foundation/KAF. 2002.

Barton, Greg. "Islam and Politics in the New Indonesia," in Jason F. Isaacson and Colin Rubenstein (eds). Islam in Asia: Changing Political Realities. New Brunswick and London: Transaction Publishers. 2002.

Chauvel, Richard. Nationalists, Soldiers, and Separatists: The Ambonese Islands From Colonialism to Revolt 1880-1950. Leiden: KITLV Press. 1990.

Djaelani, Abdul Qadir. Agama dan Separatisme menjadi Landasan Konflik Maluku dan Poso. Jakarta: Yayasan Pengkajian Islam Madinah AlMunawwarah, 2001. 
Esposito, John L. Islamic Threat: Myth or Reality?. revised edition. New York and Oxford: Oxford University Press, 1995.

Geertz, Clifford. Islam Observed: Religious Development in Marocco and Indonesia. New Haven and London: Yale University Press. 1968.

Hasan, Noorhaidi. "Faith and Politics: The Rise of the Laskar Jihad in the Era of Transition in Indonesa." Indonesia 73 (April 2002).

Horowitz, Donald L. The Deadly Ethnic Riot. Berkeley, Los Angeles, London: University of California Press, 2001.

International Crisis Group (ICG) in Peter Searle. "Ethnic-Religious Conflicts: Rise or Decline? Recent Developments in Southeast Asia." Contemporary Southeast Asia, Vol. 24, No. 1, April 2002.

Joseph, Suad and Barbara I.K. Origins (eds). Muslim-Christian Conflicts; Economic, Political, and Social Origins. Colorado: Westview Press. 1978.

Jubilee Campaign United Kingdom. "Analysis of the Sectarian Conflict in Maluku and Its Role in the Islamisation of Indonesia." A Report Issued in December 1999.

Kastor, Rustam. Fakta, Data, dan Analisa Konspirasi RMS dan Kristen Menghancurkan Umat Islam di Ambon-Maluku. Yogyakarta: Wihdah Press. 2000.

-. Suara Maluku Membantah, Rustam Kastor Menjawab. Yogyakarta: Wihdah Press. 2000.

. Badai Pembalasan Laskar Mujabidin: Ambon dan Maluku: Mei-Juli 2000. Yogyakarta: Wihdah Press. 2000.

Majelis Ulama Indonesia. Merajut Damai di Maluku: Telaah Konflik Antarumat 1999-2000. Jakarta: MUI \& Yayasan Pustaka Umat. 2000.

McAmis, Robert Day. Malay Muslims: The History and Challenge of Resurgent Islam in Southeast Asia. Grand Rapids: William B. Eerdmans Publishing Company. 2002.

Putuhena, M. Husni. Buku Putih Tragedi Kemanusiaan dalam Kerusuban di Maluku. Maluku: Lembaga Eksistensi Muslim Maluku. 1999.

Ratnawati, Tri. "In Search of Harmony in Moluccas: A Political History Approach," in Chaidar S. Bamualim et al. (eds). Communal Conflicts in Contemporary Indonesia. Jakarta: Pusat Bahasa 
dan Budaya IAIN Jakarta \& The Konrad Adenauer Foundation (KAF). 2002.

Reid, Anthony. "A Religious Revolution." Southeast Asia in the Age of Commerce 1450-1680, Vol. II.

Shihab, Alwi. "Pertemuan Islam-Kristen di Indonesia: Sebuah Tinjauan Historis," in Islam Inklusif: Menuju Sikap Terbuka dalam Beragama. Bandung: Penerbit Mizan. 1998.

Suaedy, Ahmad, et al. (eds). Luka Maluku Militer Terlibat. Jakarta: Institut Studi Arus Informasi. 2000.

Steenbrink, Karel A. "The Pancasila Ideology and an Indonesian Muslim Theology of Religions," in Jacques Waardenburg, Muslim Perceptions of Other Religions. New York and Oxford: Oxford University Press. 1999.

Tuasikal, Umar. Quo Vadis Modus Vivendi Antar Umat Beragama di Ambon. Jakarta: Himpunan Keluarga Muslimin Maluku. 2000.

Trijono, Lambang. "Peran Komunikasi dalam Konflik dan Untuk Perdamaian," in Lukas S. Ispandriarno et al. (eds). Media-MiliterPolitik: Crisis Communication: Perspektif Indonesia dan Internasional. Yogyakarta: Friedrich Ebert Stiftung \& Galang Press. 2002.

Van Klinken, Gerry. "What Caused the Ambon Violence?." Inside Indonesia. No. 60. October-December 1999.

\section{Newspapers and Reports}

"Perang Agama, Siapa Bilang?.” Tempo, February 2-8. 1999.

"Bom Hidup Mujahidin Menunggu Komando." Abadi, No. 18, March 17. 1999.

Kompas. March 4. 1999.

------. July 30. 1999.

-------. April 10. 2000.

Media Dakwah. December 29. 1999.

Republika. December 17. 2002.

Tempo. December 20-26. 1999.

-----.. March 13. 2002.

-------. February 10. 2003. 